\title{
Fake drugs: lessons for the world
}

Dora Akunyili is director-general of Nigeria's National Agency for Food and Drug Administration and Control (NAFDAC). Since her appointment in 2001, she has led a successful crusade against counterfeit pharmaceuticals, which are responsible for millions of deaths worldwide each year. Nature caught up with her last week in Washington DC.

\begin{abstract}
What is top of your agenda at the moment? I want to bring the incidence of fake drugs in Nigeria down to single-digit levels. And I want to institutionalize our processes and systems at NAFDAC so that it is as strong as food- and drug-regulatory agencies in developed countries. That would not only save lives but would help our food and drug industries to capture the African market.
\end{abstract}

\section{Since you took office the proportion of} fake drugs in Nigeria has fallen from some $41 \%$ to around $10 \%$. What did you do?

We achieved that through restructuring NAFDAC, repositioning staff for better effectiveness, and public enlightenment campaigns - alerting people to the fact that there was a problem. We also started focusing on those countries that supply these drugs to Nigeria, especially India and China. We put in place Indian and Chinese nationals as independent analysts in these countries to recertify drugs before they are imported into Nigeria. The drug importers pay them.

We also go anywhere in the world to inspect facilities producing drugs, food, cosmetics or any NAFDAC-regulated product before we register the product. And we insist on preshipment information before drugs are accepted in Nigeria. We must get all information, from which drug is coming in what quantity to the final detail of the conveyance vessel. And before the financial import document is processed by Nigerian banks, they must get NAFDAC clearance. Above all, we insist on a certificate of free sale. This states that before a drug is registered in Nigeria it must already be used in the country of production.

\footnotetext{
What about the drugs that slip through? We mop up what is already in circulation by sustained, systematic surveillance. We depend on reports from the public, from patients, from hospitals, even from journalists. In 2003, it was Nigerian journalists who reported the deaths of children during open-heart surgery in a teaching hospital. We investigated and found that the drugs used during the surgery were substandard. In this mopping up exercise of fake products, we have closed three different drug markets and sealed up shops.
}

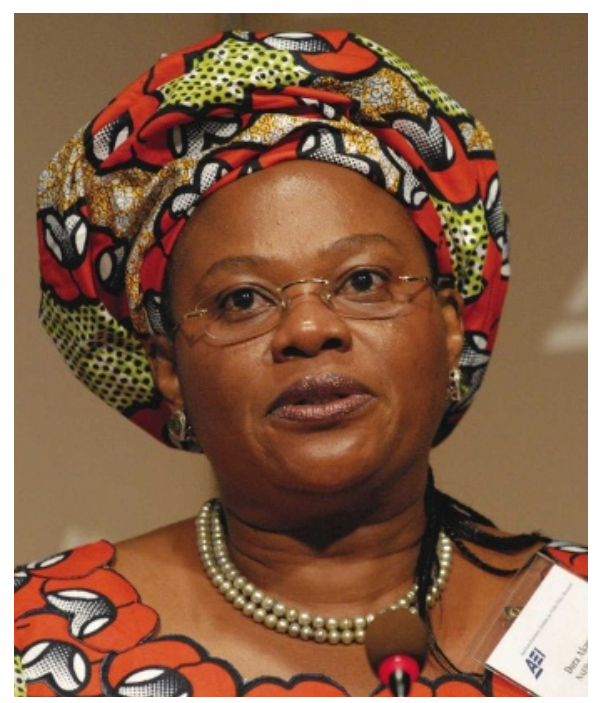

Has the problem simply moved elsewhere? When Nigeria got too hot for drug counterfeiters, they started migrating to other West African countries and became a big problem to them. We instituted the West African Drug Regulatory Authorities Network as a platform to work with other countries to encourage them in this fight. We are also occupying an important position in the International Medical Products AntiCounterfeiting Taskforce, for which I am the vice-chair.

\section{Do you get support from the Indian and Chinese authorities?}

They are forced to support us. I don't think they actually wanted to support us because fighting these counterfeit drugs weakens their economy. That is why they have strong regulations for drugs meant for domestic consumption and little or no regulation for drugs meant for export. We have banned 30 Indian and Chinese companies and one Pakistani company from importing drugs into Nigeria. We have better support from India than from China.

Do you think that the execution last year of the head of the Chinese drug-regulatory agency was an effective measure?

It was not effective. It was a face-saving measure. It was because America had spoken. If the Chinese government is serious, then who are the workers that worked with the man? Who facilitated what he did? No chief regulatory officer could do what he did alone. There are people farther down the ladder. We are still waiting for the Chinese government to tell us who they are and what they have done to them.

I believe that another reason they killed him is probably because Chinese children died. If all of those drugs were for export, they wouldn't have killed him. It was because their own people had been affected.

You were the subject of an assassination attempt five years ago. How safe do you feel nowadays?

Since 2003 I have, happily, not been shot again. But I still experience threats here and there and I don't think they have given up. But my security has been beefed up so much that it is getting more difficult for them. Right now I have at least eight policemen around me all the time and they are well-armed.

\section{Why has nobody been convicted yet?}

It is a very, very unfortunate situation. After the shooting, the government was able to get at the people who organized it because before it happened they were boasting that after December 2003 there would be no NAFDAC, and that I would not live to see 2004 . So one arrest led to another. The case started in 2004 and lasted over one and a half years with 58 exhibits and 19 witnesses. And after all that, the judge's verdict was that he had no jurisdiction to hear the case. The case was sent to appeal court. The appeal court ruled against the judge and said: 'you must hear it, you have jurisdiction'. That was early last year. And for over 12 months there has been adjournment on that case, after it was sent back to the high court. Even last week we were in court and it was adjourned for next week.

\section{Are fake drugs an issue that people in Washington should worry about?}

The problem is already here in America. And it is one that can swallow the whole human race if nothing is done. Resistant strains of microorganisms caused by substandard antibiotics do not need visas to travel from country to country.

Interview by Meredith Wadman. 